\title{
SELF-EFFICACY AND MOTIVATION: IMPROVING BIOLOGY LEARNING OUTCOMES OF SENIOR HIGH SCHOOL STUDENTS
}

\author{
Fahmie Firmansyah*, Ratna Komala, and Rusdi \\ Master Program of Biology Education, Faculty of Mathematics and Natural Sciences, Universitas \\ Negeri Jakarta, Jakarta, Indonesia \\ *Corresponding e-mail: fahmieeefirmansyah@gmail.com
}

\begin{abstract}
There are many things that are factors of student learning success, including self-efficacy and motivation. Self-efficacy and motivation will have a strong influence on students in achieving good learning outcomes. The aim of this study was to see the effect of self-efficacy and motivation on Biology learning outcomes. This research was conducted at SSHS 1 of Cilegon city, this study used survey research methods using a quantitative-causal approach using path analysis. The sample used in this study was 144 students. The results of the research, the path coefficient of self-efficacy towards motivation was obtained at 0.596, the motivation for learning outcomes was 0,600 and self-efficacy toward learning outcomes through motivation was 0.358 . It can be concluded that there was a direct effect of self-efficacy on motivation, there was a direct effect of motivation on Biology learning outcomes, and there was an indirect effect of self-efficacy on Biology learning outcomes through motivation.
\end{abstract}

Keywords: Biology learning outcomes, motivation, self-efficacy

(C) 2018 Department of Biology Education, FTTE, University of Muhammadiyah Malang, Indonesia

\section{INTRODUCTION}

Learning is a process where a person gets an experience to get a new knowledge. Learning is also interpreted as a change in behavior that survives in certain capacities that are obtained or generated from the experience gained (Schunk, 2012). This behavior change is in the form of cognitive, affective, and psychomotor abilities. To see the success of a learning process requires an overview in the form of learning assessment. The purpose of this assessment is to see the extent of the success of the learning process.

In carrying out learning activities, students must have confidence in their own abilities and have high learning motivation to be able to complete the learning process activities well. Student learning success will also be a material review that activities and learning plans are achieved well. Based on the results of the questionnaire of $11^{\text {th }}$-grade high school biology learning outcomes in State Senior High Schools (SSHS) 1, 2, 3, and 5 of Cilegon city stated that $62.5 \%$ of students' biology learning outcomes were not satisfactory or below standard. The low learning outcomes of biology are caused by a variety of factors including students having difficulty understanding the terms found in biology, the difficulty of students in understanding the material. In addition, there are internal factors (personality) that can also affect student learning outcomes. According to Ciorbea and Pasarica (2013) states that there is a relationship between personality and student learning outcomes or student academic achievement. One part of personality is selfefficacy and motivation.

Self-efficacy is a person's belief in his own ability to be able to do a task or work. According to Atoum and Al-momani (2018), self-efficacy is a person's belief in success or failure in carrying out tasks. According to Köseoğlu (2015), self-efficacy is to believe in the ability and strength that it has in working, studying, and becoming a feature of success in gaining the academic achievement. Self-efficacy will give strength to the internal students to believe in their ability to be able to complete every work they do, this is important for students to have so that students are able to follow the learning process well and be able to complete the task of learning well. Self-efficacy is needed by someone to be able to regulate and act in achieving their goals. According to Schunk (2012), self-efficacy is a 
belief in what a person can do, and not about what the person must do.

There are three dimensions in self-efficacy, namely: 1) Level or Magnitude: belief in his own ability that is able to do tasks/work at various different levels of difficulty. 2) Strength: belief that someone has that he has the ability and endurance in doing a task/job. 3) Generality: person's belief in his own ability to be able to do tasks/work in various conditions (de Noyelles, Hornik, \& Johnson, 2014).

Other personality factors that play a role in student learning success are motivation, motivation is a process carried out by someone to achieve a goal by considering the intensity, direction, persistence (Robbins \& Judge, 2012). According to Remi, Abdul-Azeez, and Toyosi (2011) states that it is defined as a force that encourages a person to achieve his personal and work goals.

Motivation gives strength to someone's internal to continue to strive more to achieve goals (Everaert, Opdecam, \& Maussen, 2017; Husamah \& Pantiwati, 2014; Widiansyah, Indriwati, Munzil, \& Fauzi, 2018). Students with high motivation will strive diligently to achieve learning goals in various ways so that students can get a high academic achievement. Motivation is an important factor for students in the learning process and is very influential in the level of learning success (Bukhari, Khan, Shahzadi, \& Khalid, 2014; Kusurkar, Ten Cate, Vos, Westers, \& Croiset, 2013).

Motivation is a business force that produces persistence and effort to do a job (Schermerhorn, Uhi-Bien, \& Richard N. Osborn, 2011). So someone with high motivation will have persistence and high effort in doing work. According to Robbins and Judge (2012), there are 3 dimensions to motivation, namely: 1) Intensity, is a person's state of the extent to which he strives to achieve his goals. 2) The direction is the condition of someone determining and choosing the method used to achieve the goal. 3) Persistence is the extent to which a person is able to maintain the efforts made to achieve the goal.

In this case, students with high motivation will have seriousness in learning and sincerity in achieving the expected goals. Students will mobilize all their abilities by paying attention to the intensity, direction, and perseverance to achieve the expected goals, namely high learning outcomes. The purpose of this study was to determine the effect of self-efficacy and motivation on biology learning outcomes.

\section{METHOD}

This study uses a survey research method with a quantitative-causal approach using path analysis, which looks at the effect of selfefficacy on motivation, the effect of motivation on learning outcomes in biology, and the effect of self-efficacy on learning outcomes through motivation. The research design is in Figure 1.

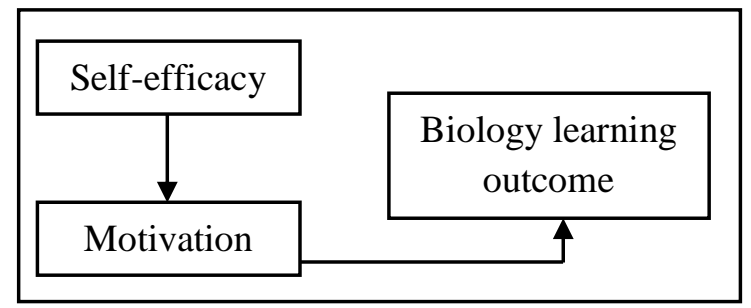

Figure 1. Path analysis research design

The population of this study was all XI-grade Mathematics and Natural Sciences students, and the sample of this study was 144 students of XIgrade Mathematics and Natural Sciences major in SSHS 1 of Cilegon city, Banten, Indonesia.

The selection of population and sample in this study is the first to use Purposive Sampling techniques from all SSHS in Cilegon city, then get SSHS 1 of Cilegon. Furthermore, for class selection using Cluster Random Sampling technique and obtained XI-grade students. Then from a total of XI-grade selected by Purposive Sampling and obtained XI-grade students majoring in mathematics and natural sciences.

Measurement of self-efficacy, motivation, and biology learning outcomes by using three instruments, namely the instrument of selfefficacy, motivation, and biology learning outcomes tests. The instrument of self-efficacy and motivation uses an opinion with five answer choices with a score scale consisting of $1=$ strongly agree, $2=$ agree, $3=$ no opinion, $4=$ disagree, and $5=$ strongly disagree. Biology learning outcomes test instruments use multiple choice, correct answers get 1 point and wrong answers get 0 points.

Before the instrument was used for data retrieval, validation was carried out by validators in the field of education and in the field of biological science. After validation, the instrument was tested to see the validity of the instrument and performed reliability tests on the instrument. The instrument of self-efficacy and motivation was tested for validity by using the Pearson product moment formula, and tested reliability using the Cronbach alpha formula. 
Firmansyah et al. / JPBI (Jurnal Pendidikan Biologi Indonesia) / 4 (3) (2018) pp. 203-208

Learning outcomes test instruments were tested for validity using the biserial point formula and tested reliability using the KR-20 formula.

\section{RESULTS AND DISCUSSION}

The instrument is first validated by the validator before used in data retrieval. The results showed that the instrument self-efficacy got a value of $3.29(0.00-4.00)$ and included a very valid category. Motivational instruments get a value of $3.33(0.00-4.00)$ and belong to a very valid category. Biology learning outcomes test instruments scored $3.27(0.00-4.00)$ and included very valid categories.

The instrument was then tested to see the validity and reliability of the instrument. Instrument trials were conducted for 37 of XIgrade students majoring in mathematics and natural sciences on biology subjects. After testing the validity by using the Pearson Product Moment formula, there are 55 questions that can be used to measure self-efficacy and 47 questions that can be used to measure motivation. The score of the reliability of self- efficacy and motivation are 0.9595 and 0.9371 , respectively. Biology learning outcomes test instruments after validity testing using biserial points there were 42 questions that can be used to measure student biology learning outcomes. Biological learning outcomes test reliability score 0.9400 .

After the validity test and reliability test were carried out, the data was collected by using instruments of self-efficacy, motivation, and tests of biology learning outcomes to 144 students majoring in mathematics and natural sciences. After measuring self-efficacy, motivation and biology learning outcomes tests for students, the first stage was a correlation test. This is important because by conducting a correlation test, is there a relationship between variables. If there is a relationship between variables, then the next test can be carried out, namely the path analysis test, but if there is no relationship between variables, the path analysis cannot be done. Correlation test using Pearson product moment formula, correlation test results data are shown in Table 1.

Table 1. The result of the correlation coefficient

\begin{tabular}{lcc}
\hline \multicolumn{1}{c}{ Correlation } & Correlation Coefficient & $\mathbf{R}^{\mathbf{2}}$ \\
\hline Self-efficacy on Motivation (r12) & $.596^{* *}$ & $.356^{*}$ \\
Motivation on Learning Outcomes of Biology (r23) & $.793^{* *}$ & $.629^{*}$ \\
Self-efficacy on Learning Outcomes of Biology (r13) & $.682^{* *}$ & $.466^{*}$ \\
\hline $\mathrm{p}<.05$ and **p $<.01$ & &
\end{tabular}

Based on the data in Table 1, the score of the correlation coefficient of self-efficacy on motivation is 0.596 , which means there is a positive and very significant relationship. These results are consistent with the research (Motlagh, Amrai, Yazdani, Abderahim, \& Souri, 2011) which states that there is a relationship between self-efficacy and student academic achievement. The score of the coefficient of determination (R2) self-efficacy on motivation is 0.356 , which means that $35.6 \%$ contributes to self-efficacy to increase motivation. The score of the Motivation on Learning Outcomes of Biology correlation coefficient is 0.793 , which means there is a positive and very significant relationship (Solomon, Corresponding, Ofori, \& Nsiahgyabaah, 2017; Erten, 2014). The score of the coefficient of determination (R2) Motivation on Learning Outcomes of Biology is 0.629, which means that $62.9 \%$ of the motivation contributes to the improvement of biology learning outcomes. The score of the correlation coefficient of self-efficacy on Learning Outcomes of Biology is 0.682, which means there is a positive and very significant relationship. The score of the coefficient of determination (R2) self-efficacy on Learning Outcomes of Biology is 0.466 , which means that $46.6 \%$ contributes to self-efficacy to the increase in biology learning outcomes.

The next step after testing the correlation coefficient is path analysis. Path analysis is done to see how much effect between variables. Path analysis results data are shown in Table 2.

\section{The direct effect of self-efficacy on motivation (p12)}

Based on the data in Table 2, the path analysis Self-efficacy score on Motivation (p12) is 0.596 and is at significance $<0.05$, which means that self-efficacy influences motivation. This means that self-efficacy has an influence on increasing student learning motivation, high self-efficacy in a field of work will improve good results through a higher performance and work (Judge \& Bono, 
2001). The results in accordance with Colquitt, LePine, and Wesson (2012) that self-efficacy and competency give strength to motivation, this motivation will improve one's internal abilities.

Table 2. The result of the Path analysis

\begin{tabular}{lcc}
\hline \multicolumn{1}{c}{ Path Analysis } & Direct effect & Indirect effect \\
\hline Self-efficacy on Motivation (p12) & $.596^{* *}$ & - \\
Motivation on Learning Outcomes of Biology (p23) & $.600^{* *}$ & - \\
$\begin{array}{l}\text { Self-efficacy on Learning Outcomes of Biology through motivation } \\
(\mathrm{p} 12)(\mathrm{p} 23)\end{array}$ & - & $.358^{* *}$ \\
\hline $\mathrm{p}<.05$ and $* * \mathrm{p}<.01$ & &
\end{tabular}

Based on the data obtained, students with high self-efficacy also have high learning motivation. This is because self-efficacy in students will influence students' learning motivation. Students with high self-efficacy will have high motivation in completing each school assignment and are able to participate in good learning activities. Conversely, students with low self-efficacy will easily give up on completing tasks and not be able to survive to solve problems in learning activities (Schunk, 2012). When students have confidence in their abilities, they will simultaneously increase their motivation to learn. Self-efficacy affects a person's level of effort and perseverance in interpreting tasks (Lunenburg, 2011).

The implication of the data from this study is that students with high self-efficacy will have high motivation as well. This is beneficial for students because students feel confident in their ability to complete each task in school learning, students' confidence in their abilities will foster a high sense of enthusiasm and motivation. So that it can be concluded that self-efficacy directly affect motivation.

\section{The direct effect of motivation on biology learning outcomes (p23)}

Table 2 showed that the direct effect of motivation on learning outcomes of biology scores is 0.600 (significance). It means that motivation affects learning outcomes of biology. This means that an increase in motivation will also affect the improvement of student biology learning outcomes. Motivation is a driving force that can increase one's enthusiasm to exert all abilities to achieve goals. This is in accordance with Schermerhorn et al., (2011) which states that motivation also produces perseverance in doing a job, and perseverance will produce good results. The motivation for learning in students will affect student learning outcomes. According to Gupta and Mili (2016), the high learning motivation will improve learning outcomes of students.
Motivation provides internal strength to students to be more active in learning and try to be stronger. Motivation will also help students in their efforts to understand the subject matter. Sukor, Mohd Ayub, Norhasnida, and Nor Khaizura (2017) stated that motivation will increase students' enthusiasm for understanding learning material. To be able to get good results, it requires ability and motivation (Colquitt et al., 2012; Zameer, Alireza, Nisar, \& Amir, 2014). Christiana (2009) stated that motivation influences and becomes a significant aspect in determining learning outcomes. Based on the research Arulmoly and Branavan (2017) stated that motivation has a significant influence on the academic achievement of middle school students. Previous studies have proven that there is an effect of motivation on student learning outcomes. These previous studies are in accordance with the data obtained by researchers, namely motivation affect students' academic performance.

The implication of the data from this study is that students with high motivation will influence the improvement of learning outcomes. Students with high motivation in learning will have sincerity, perseverance, and high enthusiasm in doing each school assignment so that students will improve their learning outcomes. It can be concluded that motivation has a direct effect on student biology learning outcomes.

The indirect effect of self-efficacy on the learning outcomes of biology through motivation (p12) (p23)

Based on the data in table 2 the Path analysis self-efficacy score on learning outcomes of biology through motivation (p12) (p23) 0.358 and are at significance $<0.05$, which means that self-efficacy affects biology learning outcomes through motivation. Self-efficacy is a person's belief in his ability to be able to do something, this belief will increase motivation and motivation will make someone diligent and try their best in achieving maximum results. 
Increasing self-efficacy in a person will increase confidence, and this belief will create motivation to continue to maintain performance in achieving goals (Schunk, 2012; Yusuf, 2011). Deora (2015) in his research stated that selfefficacy affect the learning outcomes of chemistry. The study shows that there is an effect of self-efficacy in increasing and decreasing student learning outcomes.

Self-efficacy gives strength to motivation, and motivation will increase internal strength in a person. Students with high self-efficacy will increase the motivation that exists in them (Ahmad \& Safaria, 2013). Çetin and Aşkun (2018) was found that increased motivation would produce the good performance in the form of good learning outcomes, this is because of motivation functions as a mediator variable between self-efficacy and student learning outcomes. When students have a goal to get good learning outcomes, then indirectly they will be motivated to learn and try harder (Schunk, 2012). Jiang, Song, Lee, and Bong (2014) state that self-efficacy is influential as a predictor of student learning outcomes in elementary and secondary schools in Korea.

The implication of the data from this study is that students with high self-efficacy will increase learning motivation, and high motivation in learning will have an impact on achieving high learning outcomes. The effect of self-efficacy is of course not directly to students' biology learning outcomes but through motivation which functions as a mediator variable that connects between self-efficacy and learning outcomes. So it can be concluded that there is an indirect effect of self-efficacy on the results of learning biology through motivation.

\section{CONCLUSION}

Based on the data obtained, it can be concluded that there is a direct effect of selfefficacy on motivation, the direct effect of motivation on learning outcomes in biology, and the indirect effect of self-efficacy on the results of learning biology through motivation. Selfefficacy and motivation have a significant influence on improving student learning outcomes, but there are still many other personality factors that influence student learning outcomes. Based on the research data that the influence of self-efficacy in improving learning outcomes is only $46.6 \%$ and the effect of motivation in improving student learning outcomes is only $62.9 \%$, this means that there are still other factors that influence the improvement of student learning outcomes that can be done by researchers in the future which will come. The number of samples used can also use more so that the data obtained will be more accurate.

Researcher's suggestion is to use more personality variables that can be used to measure student learning outcomes, so that it can be seen what factors influence student learning outcomes. Furthermore, the researchers also suggested that more samples be used and more schools are used and not just use one school.

\section{REFERENCES}

Ahmad, A., \& Safaria, T. (2013). Effects of selfefficacy on students' academic performance. Journal of Educational, Health and Community Psychology, 2(1), 22-29. https://doi.org/10.12928jehcp.v2i1. 3740

Arulmoly, C., \& Branavan, A. (2017). The impact of motivation on student's academic achievement and learning outcomes in mathematics among secondary school students in Nigeria. International Journal of Scientific and Research Publications, 7(5), 115-126.

Atoum, A. Y., \& Al-momani, A. (2018). Perceived self-efficacy and academic achievement among Jordanian students. Trends in Technical \& Scientific Research, 3(1), 1-6.

Bukhari, T. Z., Khan, J., Shahzadi, I., \& Khalid, A. (2014). Mediating role of motivation to learn in determining e-learning outcomes: A conceptual study. International Journal of Information, Business and Management, 6(2), 179-189.

Çetin, F., \& Aşkun, D. (2018). The effect of occupational self-efficacy on work performance through intrinsic work motivation. Management Research Review, 41(2), 186-201. https://doi.org/10. 1108/MRR-03-2017-0062

Ciorbea, I., \& Pasarica, F. (2013). The study of the relationship between personality and academic performance. In Procedia Social and Behavioral Sciences (Vol. 78, pp. 400-404). https://doi.org/10.1016/j. sbspro.2013.04.319

Colquitt, J., LePine, J., \& Wesson, M. (2012). Organizational behavior: Improving performance and commitment in the workplace. New York: McGraw-Hill 
Education

de Noyelles, A., Hornik, S. R., \& Johnson, R. D. (2014). Exploring the dimensions of selfefficacy in virtual world learning: Environment, task, and content. Journal of Online Learning \& Teaching, 10(2), 255271. https://doi.org/10.1016/j.jsurg.2012.0 2.002

Deora, N. (2015). Impact of academic self efficacy and locus of control on academic achievement of high school students. Indian Journal of Mental Health, 2(2), 197-202.

Everaert, P., Opdecam, E., \& Maussen, S. (2017). The relationship between motivation, learning approaches, academic performance and time spent. Accounting Education, 26(1), 78-107. https://doi.org/ 10.1080/09639284.2016.1274911

Gupta, P. K., \& Mili, R. (2016). Impact of academic motivation on academic achievement: A study on high schools students. European Journal of Education Studies, 2(10), 43-51.

Husamah, H., \& Pantiwati, Y. (2014). Cooperative learning STAD-PJBL: Motivation, thinking skills, and learning outcomes of biology department students. International Journal of Education Learning and Development, 2(1), 77-94.

Jiang, Y., Song, J., Lee, M., \& Bong, M. (2014). Self-efficacy and achievement goals as motivational links between perceived contexts and achievement. Educational Psychology, 34(1), 92-117. https://doi.org/ 10.1080/01443410.2013.863831

Köseoğlu, Y. (2015). Self-ffficacy and academic achievement -A case from Turkey. Journal of Education and Practice, 6(29), 131-141.

Kusurkar, R. A., Ten Cate, T. J., Vos, C. M. P., Westers, P., \& Croiset, G. (2013). How motivation affects academic performance: a structural equation modelling analysis. Advances in Health Sciences Education, 18(1), 57-69. https://doi.org/10.1007/s104 59-012-9354-3

Lunenburg, F. C. (2011). Self-efficacy in the workplace: Implications for motivation and performance. International Journal of Management, Business, and Administration, 14(1), 1-6.

Motlagh, S. E., Amrai, K., Yazdani, M. J., Abderahim, H. A., \& Souri, H. (2011). The relationship between self-efficacy and academic achievement in high school students. Procedia - Social and Behavioral Sciences, 15, 765-768. https://doi.org/10. 1016/j.sbspro.2011.03.180

Remi, A. J., Abdul-Azeez, I. A., \& Durowoju, S. T. (2011). An empirical study of the motivational factors of employees in Nigeria. International Journal of Economics and Finance, 3(5), 227-233. https://doi.org/10.5539/ijef.v3n5p227

Robbins, S., \& Judge, T. A. (2012). Organizational behavior. New Jersey: Pearson Education.

Schermerhorn, J. R., Uhi-Bien, M., \& Richard N. Osborn. (2011). Organizational behavior. New York: Wiley. https://doi.org/9780470878200

Schunk, D. H. (2012). Learning theories: An educational perspective (6th ed.). Boston: Allyn \& Bacon.

Sukor, R., Mohd Ayub, A. F., Norhasnida, Z., \& Nor Khaizura, A. R. (2017). Influence of students' motivation on academic performance among non-food science students taking food science course. International Journal of Academic Research in Progressive Education and Development, 6(4), 104-112. https://doi. org/10.6007/IJARPED/v6-i4/3528

Widiansyah, A. T., Indriwati, S. E., Munzil, M., \& Fauzi, A. (2018). I-invertebrata as an android-based learning media for molluscs, arthropods, and echinoderms identification and its influence on students' motivation. JPBI (Jurnal Pendidikan Biologi Indonesia), 4(1), 43-52. https://doi.org/10. 22219/jpbi.v4i1.5476 43

Yusuf, M. (2011). The impact of self-efficacy, achievement motivation, and self-regulated learning strategies on students' academic achievement. In Procedia-Social and Behavioral Sciences (Vol. 15, pp. 26232626).https://doi.org/10.1016/j.sbspro.201 1.04 .158

Zameer, H., Alireza, S., Nisar, W., \& Amir, M. (2014). The impact of the motivation on the employe performance in beverage industry of Pakistan. International Journal of Academic Research in Accounting, Finance and Management Sciences, 4(1), 293-298. https://doi.org/10.6007/IJARAF MS/v4-i1/630 